\title{
Serotonin-induced vascular permeability is mediated by transient receptor potential vanilloid 4 in the airways and upper gastrointestinal tract of mice
}

\author{
Jeffri S. Retamal $\mathbb{1}^{1,2} \cdot$ Megan S. Grace ${ }^{3,4,5,6} \cdot$ Larissa K. Dill ${ }^{3,7} \cdot$ Paulina Ramirez-Garcia ${ }^{1,2} \cdot$ Scott Peng ${ }^{1,2}$. \\ Arisbel B. Gondin ${ }^{1,2} \cdot$ Felix Bennetts $^{1} \cdot$ Sadia Alvi ${ }^{1}$ - Pradeep Rajasekhar ${ }^{1,2}$ - Juhura G. Almazi ${ }^{3}$. \\ Simona E. Carbone $\mathbb{D}^{1,2} \cdot$ Nigel W. Bunnett $\mathbb{D}^{1,2,8} \cdot$ Thomas P. Davis ${ }^{2} \cdot$ Nicholas A. Veldhuis $\mathbb{D}^{1,2}$. \\ Daniel P. Poole $\mathbb{C}^{1,2} \cdot$ Peter Mclntyre ${ }^{3,9}$
}

Received: 14 September 2020 / Revised: 12 March 2021 / Accepted: 14 March 2021 / Published online: 15 April 2021

(c) The Author(s), under exclusive licence to United States and Canadian Academy of Pathology 2021

\begin{abstract}
Endothelial and epithelial cells form physical barriers that modulate the exchange of fluid and molecules. The integrity of these barriers can be influenced by signaling through G protein-coupled receptors (GPCRs) and ion channels. Serotonin (5HT) is an important vasoactive mediator of tissue edema and inflammation. However, the mechanisms that drive 5-HTinduced plasma extravasation are poorly defined. The Transient Receptor Potential Vanilloid 4 (TRPV4) ion channel is an established enhancer of signaling by GPCRs that promote inflammation and endothelial barrier disruption. Here, we investigated the role of TRPV4 in 5-HT-induced plasma extravasation using pharmacological and genetic approaches. Activation of either TRPV4 or 5-HT receptors promoted significant plasma extravasation in the airway and upper gastrointestinal tract of mice. 5-HT-mediated extravasation was significantly reduced by pharmacological inhibition of the 5$\mathrm{HT}_{2 \mathrm{~A}}$ receptor subtype, or with antagonism or deletion of TRPV4, consistent with functional interaction between 5-HT receptors and TRPV4. Inhibition of receptors for the neuropeptides substance P (SP) or calcitonin gene-related peptide (CGRP) diminished 5-HT-induced plasma extravasation. Supporting studies assessing treatment of HUVEC with 5-HT, CGRP, or SP was associated with ERK phosphorylation. Exposure to the TRPV4 activator GSK1016790A, but not 5-HT, increased intracellular $\mathrm{Ca}^{2+}$ in these cells. However, 5-HT pre-treatment enhanced GSK1016790A-mediated $\mathrm{Ca}^{2+}$ signaling, consistent with sensitization of TRPV4. The functional interaction was further characterized in HEK293 cells expressing 5- $\mathrm{HT}_{2 \mathrm{~A}}$ to reveal that TRPV4 enhances the duration of 5-HT-evoked $\mathrm{Ca}^{2+}$ signaling through a PLA $\mathrm{P}_{2}$ and PKC-dependent mechanism. In summary, this study demonstrates that TRPV4 contributes to $5-\mathrm{HT}_{2 \mathrm{~A}}$-induced plasma extravasation in the airways and upper GI tract, with evidence supporting a mechanism of action involving SP and CGRP release.
\end{abstract}

These authors contributed equally: Jeffri S. Retamal, Megan S. Grace

Nicholas A. Veldhuis

Nicholas.Veldhuis@monash.edu

$\triangle$ Daniel P. Poole

Daniel.Poole@monash.edu

1 Drug Discovery Biology Theme, Monash Institute of Pharmaceutical Sciences, Monash University, Parkville, VIC, Australia

2 ARC Centre of Excellence in Convergent Bio-Nano Science \& Technology, Monash University, Parkville, VIC, Australia

3 School of Medical Sciences and Health Innovations Research Institute, RMIT University, Bundoora, VIC, Australia
4 Department of Physiology, School of Medicine Nursing and Health Sciences, Monash University, Clayton, VIC, Australia

5 Baker IDI Heart and Diabetes Institute, Melbourne, VIC, Australia

6 School of Clinical Medicine, Faculty of Medicine, University of Queensland, Brisbane, QLD, Australia

7 Department of Neuroscience, Central Clinical School, Monash University, Melbourne, VIC, Australia

8 Department of Molecular Pathobiology, New York University College of Dentistry, New York, NY, USA

9 The Florey Institute of Neuroscience and Mental Health, Parkville, VIC, Australia 


\section{Introduction}

The vasculature performs several important functions that are essential for maintaining fluid homeostasis. Endothelial cells make up the physical barrier in blood vessels that enables the control of fluid and molecule exchange from the circulation to the surrounding tissues. Physiological regulation of these barriers controls the extravasation of plasma proteins through inter-endothelial gaps, where cytoskeletal reorganization and disassembly of VE-cadherin junctions are essential regulators of endothelial permeability [1]. Disruption of these processes, as occurs in disease, is associated with unregulated movement and accumulation of fluids, leading to tissue edema.

Several inflammatory mediators, including proteases (e.g., thrombin), histamine, substance P (SP), and serotonin (5-HT) can activate specific receptors on vascular endothelial cells to promote changes in endothelial permeability. These changes can be mediated by an increase in intracellular calcium $\left(\left[\mathrm{Ca}^{2+}\right]_{\mathrm{i}}\right)$ and activation of signaling pathways that regulate the contractile apparatus of cells, leading to cytoskeletal remodeling and disassembly of VE-Cadherin junctions [2]. This, in turn, causes endothelial cell contraction and cell junction disruption, resulting in increased endothelial permeability and tissue edema [2-6]. For example, increased endothelial $\left[\mathrm{Ca}^{2+}\right]_{\mathrm{i}}$ in pulmonary blood vessels leads to their constriction and to subsequent edema formation $[3,7,8]$.

It has been demonstrated that systemic administration of 5-HT produces detrimental effects on the integrity of the endothelial barrier, leading to plasma extravasation into the surrounding tissue [9]. The biological actions of 5-HT are mediated through specific serotonin receptors $\left(5-\mathrm{HT}_{1-7}\right)$ [10], all of which are G protein-coupled receptors (GPCRs), with the notable exception of the 5- $\mathrm{HT}_{3}$ ligand-gated ion channel [11]. In addition to their well-defined roles in neurotransmission and clinical association with the pathogenesis of neurological diseases and neuropsychiatric disorders, 5-HT receptors are also key regulators of the homeostatic control of vasoconstriction and vascular permeability [12-14].

As previously described, elevated $\left[\mathrm{Ca}^{2+}\right]_{\mathrm{i}}$ in endothelial cells is required to cause barrier dysfunction. This elevation in $\left[\mathrm{Ca}^{2+}\right]_{i}$ is triggered by mechanical stimuli or by activation of GPCRs and occurs in two phases, initiated by the release of $\mathrm{Ca}^{2+}$ from ER-stores and followed by entry of extracellular $\mathrm{Ca}^{2+}$ through cation channels [15]. Additionally, GPCR activation can also promote $\mathrm{Ca}^{2+}$ entry by activating cation channels, including transient receptor potential channels (TRP), which are the main nonselective cation channels in endothelial cells $[1,16]$. The principal TRP channels that mediate endothelial cell permeability are TRPM2, TRPC1, 4 and 6 and vanilloid family members TRPV1 and 4 [17].

Transient Receptor Potential Vanilloid 4 (TRPV4) is an established enhancer of vascular permeability and edema that is expressed by a variety of cells including endothelia, peripheral sensory neurons, and immune cells [18-21]. TRPV4 is also a recognized promoter of neurogenic inflammation through enhanced release of neuropeptides, including SP and calcitonin gene-related peptide (CGRP), from peptidergic peripheral nerve endings [22, 23]. The sensitivity to ligand or mechanical activation, as well as the magnitude and duration of TRPV4 activity can be augmented by functional interactions (termed 'coupling') with GPCRs. These interactions are also known to be reciprocal, where functional coupling of a GPCR to an ion channel such as TRPV4 can lead to augmentation of GPCR signaling outputs. Furthermore, coupling between GPCRs and TRPV4 is proposed to contribute to disease-associated processes, including neurogenic inflammation and pain [24].

A well-characterized example of reciprocal coupling is illustrated through functional interactions between proteaseactivated receptors 1 and 2 (PAR1 and PAR2) and TRPV4 $[20,25,26]$. PAR activation can "sensitize" or reduce the activation threshold through channel phosphorylation and enhance TRPV4 signaling through the production of endogenous TRPV4 activators (e.g., arachidonic acid and 5',6'-EET) [25-27]. Conversely, TRPV4 activity augments PAR1- and PAR2-dependent signaling, and this bidirectional PAR-TRPV4 relationship drives a significant component of PAR-evoked edema [20, 26, 27].

A variety of cell types co-express 5-HT receptors and TRPV4, highlighting their broader potential to functionally interact. Indeed, studies have demonstrated an important role for TRPV4 as an enhancer of 5-HT signaling associated with arterial smooth muscle proliferation [28, 29], pulmonary artery smooth muscle contraction [8, 19], itch [30], and visceral pain [31]. Immunohistochemistry and in situ hybridization studies have demonstrated that nociceptive dorsal root ganglion neurons mainly express 5 -HT receptor subtypes $2 \mathrm{~A}$ and $3[32,33]$. Activation of $5-\mathrm{HT}_{2 \mathrm{~A}}$ expressed by these neurons promotes 5 -HT-induced nociception and the release of SP and CGRP from peripheral nerve terminals, leading to a sustained increase in vascular permeability [34-38]. Neurogenic inflammation is initiated by the release of these neuropeptides [36, 39] and further studies have supported the involvement of neurogenic inflammation in 5-HT-evoked plasma extravasation by demonstrating significant inhibition of plasma protein extravasation with antimigraine drugs [40, 41].

Although there is strong evidence to support the importance of TRPV4 as an amplifier of 5-HT receptor signaling, the relative contribution of TRPV4 to 5-HT-induced edema 
has not been defined in detail. We hypothesized that 5-HTinduced plasma extravasation is augmented by TRPV4 activity and is mediated, in part, through release of SP and CGRP from nerve fibers associated with microvasculature. In the present study, we found that the systemic administration of 5-HT-induced plasma extravasation in the airway and upper GI tract, particularly by the activation of $5 \mathrm{HT}_{2 \mathrm{~A}}$, where the pharmacological inhibition or genetic deletion of TRPV4 attenuates 5-HT-induced plasma extravasation in the airways and upper GI tract, indicating a reciprocal coupling between 5- $\mathrm{HT}_{2 \mathrm{~A}}$ and TRPV4 in vivo. In addition, in vitro studies indicated that $5-\mathrm{HT}_{2 \mathrm{~A}}$ interact with TRPV4 through the activation of $\mathrm{PLA}_{2}$ and PKC. Moreover, we establish that inhibitors of $\mathrm{NK}_{1} \mathrm{R}$ (SR140333) or the CGRP receptor (Olcegepant; BIBN4096) block 5-HT- and TRPV4-induced plasma extravasation in mice. These observations provide further mechanistic understanding of the important contribution that GPCR-TRP channel interactions have in fundamental biological processes, including the control of vascular permeability.

\section{Materials and methods}

\section{Drugs and reagents}

Evans Blue dye and GSK1016790A were purchased from Sigma-Aldrich (St. Louis, MO); 5-HT, HC067047, SR140333, GF 109203X (GFX), and BIBN 4096 (Olcegepant) were purchased from Tocris Bioscience (Bristol, UK); YM 26734 was from Cayman Chemical; WAY100635 Maleate, GR 55562 dihydrochloride, GR113808 and SB 269970 hydrochloride were purchased from Abcam Australia (Melbourne, VIC Australia). Ketanserin and RS127445 were purchased from Selleck Chemicals (Houston, TX. USA); Evans Blue was dissolved in sterile $0.9 \%$ saline. All drugs administered to mice were prepared on the day of experimentation in sterile 1\% dimethyl sulfoxide (DMSO) in $0.9 \%$ saline.

\section{Animals}

All animal experiments adhered to the ARRIVE guidelines [42] and were carried out in accordance with the Guide for the Care and Use of Laboratory Animals. This study was approved by the Animal Ethics Committees of RMIT and Monash Institute of Pharmaceutical Sciences. Wild-type C57B1/6J and $\mathrm{TRPV}^{-1-}$ (kindly provided by Dr. W Liedtke, Duke University) (6-12 weeks, male) were obtained from the Animal Resources Center (Canning Vale, WA), or from Monash Animal Research Platform, Monash University. All animals were maintained in a temperature- controlled $\left(24^{\circ} \mathrm{C}\right)$ environment with a $12 \mathrm{~h}$ light/dark cycle and with access to food and water ad libitum.

\section{Measurement of plasma extravasation}

Mice were anaesthetized with a combination of Ketamine $(100 \mathrm{mg} / \mathrm{kg}$ i.p.) and Xylazine $(10 \mathrm{mg} / \mathrm{kg}$ i.p. $)$ and kept on a warming pad. The skin at the throat was removed to expose the jugular veins. Substances were i.v. administered by passing a needle through the pectoralis major muscle to prevent bleeding on withdrawal. Evans Blue dye $(20 \mathrm{mg} / \mathrm{kg})$ or $0.9 \%$ saline were administered into the jugular vein, $1 \mathrm{~min}$ before injection of agonist (5-HT or GSK1016790A, dosing as indicated in relevant sections) or vehicle (1\% DMSO in $0.9 \%$ saline). Mice were killed (5 min postagonist administration) by exsanguination and perfused with saline solution. Tissue samples were collected, weighed, and placed in formamide $\left(\geq 18 \mathrm{~h}\right.$ at $\left.37^{\circ} \mathrm{C}\right)$ to facilitate dye extraction. Absorbance of the extracts was determined against standard concentrations of Evans Blue at $620 \mathrm{~nm}$ using a FlexStation III plate reader (Molecular Devices, Sunnyvale, CA). Antagonists of $5-\mathrm{HT}_{1 \mathrm{~A}}$ (WAY$100635,80 \mu \mathrm{g} / \mathrm{kg})[43], 5-\mathrm{HT}_{1 \mathrm{~B}}(\mathrm{GR} 55562,300 \mu \mathrm{g} / \mathrm{kg})$ [44], 5- $\mathrm{HT}_{2 \mathrm{~A}}$ (ketanserin, $2 \mathrm{mg} / \mathrm{kg}$ ) [45], 5- $\mathrm{HT}_{2 \mathrm{~B}}$ (RS$127445,300 \mu \mathrm{g} / \mathrm{kg}$ ) [46], 5-HT 4 (GR 113808, $1 \mathrm{mg} / \mathrm{kg}$ ) [47], $\quad 5-\mathrm{HT}_{7} \quad(\mathrm{SB} 269973, \quad 300 \mu \mathrm{g} / \mathrm{kg}) \quad$ [46], $\quad$ TRPV4 (HC0670471, $10 \mathrm{mg} / \mathrm{kg}), \mathrm{NK}_{1} \mathrm{R}$ (SR140333, $1 \mathrm{mg} / \mathrm{kg}$ ), or CGRP receptor (Olcegepant, $1 \mathrm{mg} / \mathrm{kg}$ ) were i.p. injected $60 \mathrm{~min}$ prior to anesthetics. Results were expressed as the amount of Evans Blue dye per wet weight tissue (ng of EB/ $\mathrm{mg}$ of tissue).

\section{Human umbilical vein endothelial cell (HUVEC) culture}

HUVEC were grown in endothelial growth medium (EGM, Lonza, Mount Waverley, VIC, Australia) containing 2\% fetal bovine serum and a SingleQuots Supplement Pack (Lonza) as described [20].

\section{Transient transfection}

Constructs of pcDNA3. $1^{+}$human 5-HT receptors subtype $1 \mathrm{~A}, 1 \mathrm{~B}, 2 \mathrm{~A}, 2 \mathrm{~B}, 4$, and $7\left(\mathrm{hHT}_{1 \mathrm{~A}-7}\right)$ plasmids were purchased from the cDNA Resource Center (Bloomsburg, PA, USA). Human Embryonic Kidney 293 cell line with tetracycline-inducible (T-Rex ${ }^{\mathrm{TM}}$ 293) TRPV4 overexpression (HEK-TRPV4) was grown at $37{ }^{\circ} \mathrm{C}$ in $5 \% \mathrm{CO}_{2}$ in DMEM containing $10 \%$ FBS $(5 \mu \mathrm{g} / \mathrm{mL}$ blasticidin S). Cells were transiently transfected with $\mathrm{hHT}_{1 \mathrm{~A}-7}$ plasmids (75 ng DNA/well, HEK-5-HT $1 \mathrm{~A}-7$ ) using the standard protocol for the FuGENE reagent system (Promega 

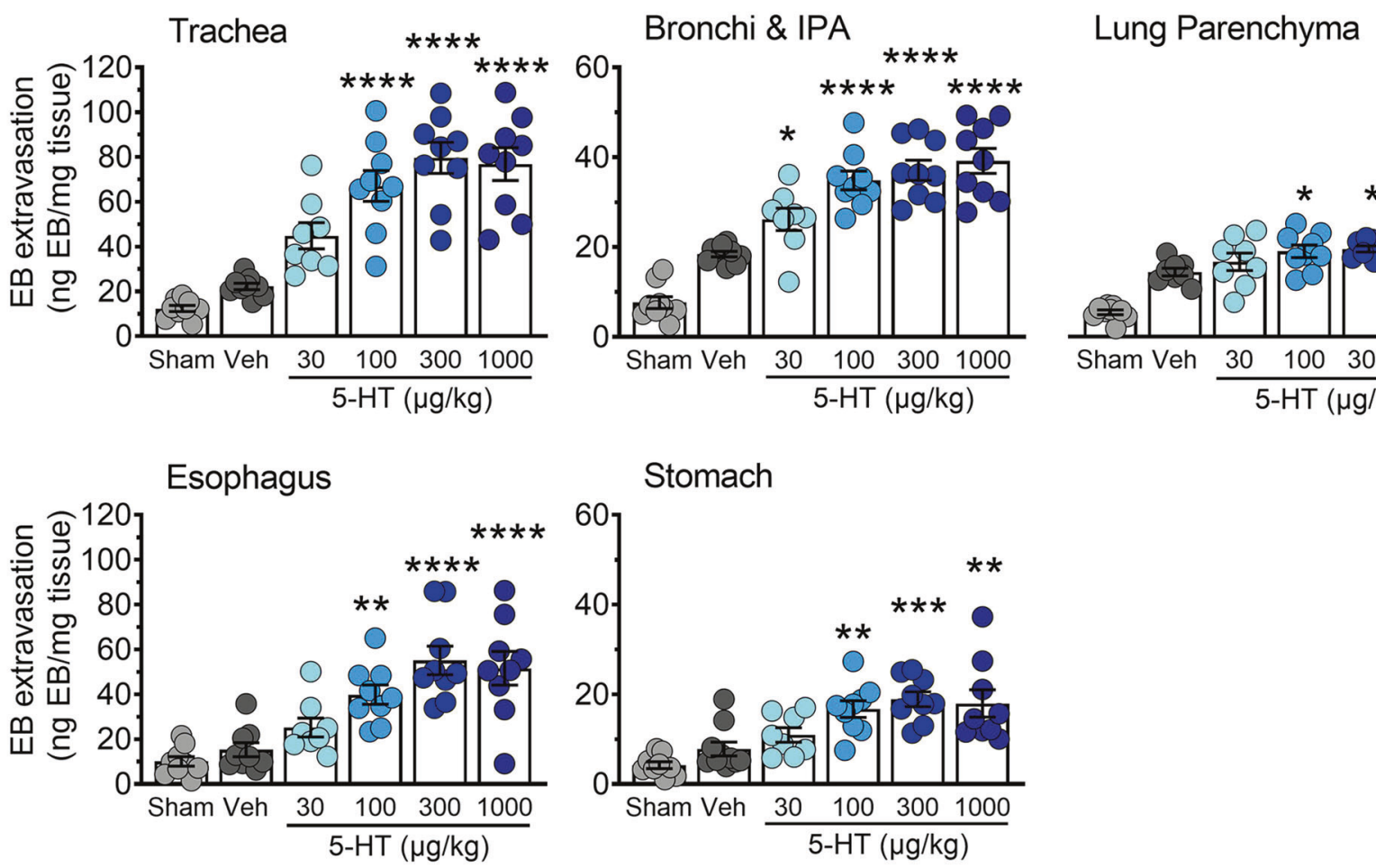

Fig. 1 5-HT causes vascular hyperpermeability in the airways and upper GI tract. Vascular hyperpermeability was assessed by the presence of Evans Blue in tissues of the airways, esophagus, and stomach following the intravenous injection of increasing concentrations of 5 -HT $(30-1000 \mu \mathrm{g} / \mathrm{kg})$. Data are expressed as mean \pm S.E.M.,

Corporation Madison, WI USA). Expression of TRPV4 was induced overnight with $0.1 \mu \mathrm{g} / \mathrm{mL}$ tetracycline.

\section{$\mathrm{Ca}^{2+}$ signaling assays}

HUVEC or HEK cells were seeded onto poly-D-lysine coated 96-well plates $(15,000$ cells/well) and cultured for $48 \mathrm{~h}$. Cells were loaded with Fura2-AM ester $(1 \mu \mathrm{M})$ in Hank's Balanced Salt Solution (HBSS) supplemented with probenecid $(2 \mathrm{mM})$ and pluronic acid $(0.5 \mu \mathrm{M})$ for $45 \mathrm{~min}$ at $37^{\circ} \mathrm{C}$. Fluorescence was measured at 340/380 $\mathrm{nm}$ excitation and $530 \mathrm{~nm}$ emission wavelengths using a FlexStation III plate reader. Baseline measurements were recorded for $20 \mathrm{~s}$ prior to agonist addition. Responses to agonists were recorded for $200 \mathrm{~s}$ post-addition. For the PKC and $\mathrm{PLA}_{2}$ inhibition assay, cells were incubated 30 min prior to 5-HT addition, as previously described with GF 109203X (GFX, $100 \mathrm{nM}$ ) [26] or YM26734 $(30 \mu \mathrm{M})$ [48].

\section{ERK phosphorylation assays}

HUVEC were seeded onto non-coated 96-well plates $(15,000$ cells/well $)$ and cultured for $48 \mathrm{~h}$. Cells were serum starved for $6 \mathrm{~h}$ and treated as described in the $n=6-9$ mice per group. $* p<0.05 ; * * p<0.01 ; * * * p<0.001 ; * * * *<<$ 0.0001 ; significantly different compared to vehicle treatment $(1 \%$ DMSO in $0.9 \%$ saline); one-way ANOVA and Dunnett's multiple comparisons test.

results section. Phospho-ERK 1/2 (pERK1/2) was measured using the AlphaScreen SureFire p-ERK 1/2 (Thr202/Tyr204) Assay Kit (PerkinElmer, USA), according to the manufacturer's specifications. Fluorescence was measured using the EnVision multilabel plate reader (PerkinElmer). Data were normalized to the positive control $(\mathrm{PDBu}, 1 \mu \mathrm{M})$.

\section{Statistical analysis}

Data were analyzed using GraphPad Prism 8 software (GraphPad Software, San Diego, CA, USA). All treatments were analyzed using one-way ANOVA with Dunnett's post-test. All data are presented as mean \pm S.E.M., with a $p$ value $<0.05$ considered to be significantly different to the null hypothesis at the $95 \%$ confidence level.

\section{Results}

\section{5-HT induces plasma extravasation in the airways and upper gastrointestinal tract}

Evans Blue dye is commonly used as an indicator of altered vascular permeability to macromolecules due to its high 


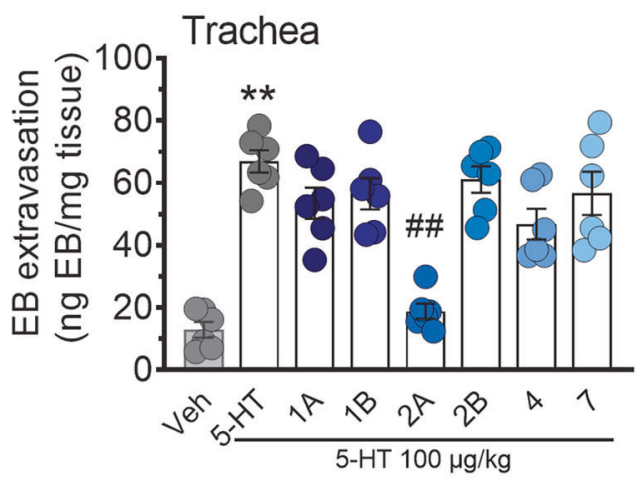

Bronchi \& IPA

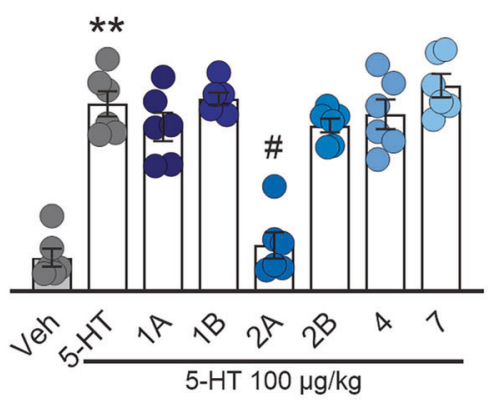

Stomach

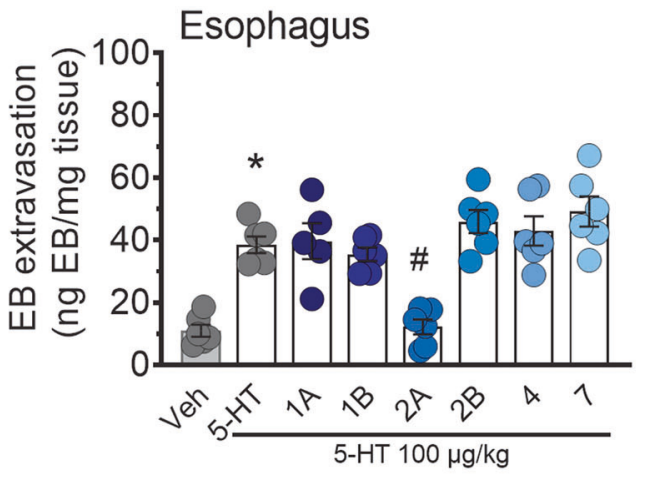

Lung Parenchyma

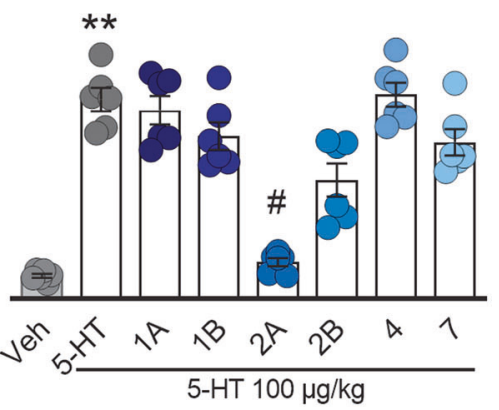

Fig. 2 5-HT-induced vascular hyperpermeability is inhibited in the airways and upper GI tract by the $5-\mathrm{HT}_{2 \mathrm{~A}}$ selective antagonist ketanserin. Effect of WAY-100635 $\left(5-\mathrm{HT}_{1 \mathrm{~A}}\right.$ antagonist, $\left.80 \mu \mathrm{g} / \mathrm{kg}\right)$, GR $55562\left(5-\mathrm{HT}_{1 \mathrm{~B}}\right.$ antagonist, $\left.300 \mu \mathrm{g} / \mathrm{kg}\right), \mathrm{RS}-127445\left(5-\mathrm{HT}_{2 \mathrm{~B}}\right.$ antagonist, $300 \mu \mathrm{g} / \mathrm{kg}$ ), GR $113808\left(5-\mathrm{HT}_{4}\right.$ antagonist, $\left.1 \mathrm{mg} / \mathrm{kg}\right)$, or SB269973 (5- $\mathrm{HT}_{7}$ antagonist, $\left.300 \mu \mathrm{g} / \mathrm{kg}\right)$ in the airways and upper GI

affinity for albumin. Under normal conditions, the vascular endothelium is impermeable to albumin, restricting albumin-bound Evans Blue to blood vessels. When inflammation occurs, albumin-bound Evans Blue is able to diffuse into surrounding tissues under conditions due to regulated, increased permeability of the vascular endothelium. Known as plasma extravasation, this process is important for promoting leukocyte infiltration, to initiate wound healing processes and subsequent swelling can also physically protect affected tissue [49].

To determine the effect of 5-HT on plasma extravasation, we examined the tissue distribution of Evans Blue following the administration of either vehicle (1\% DMSO in $0.9 \%$ saline) or 5 -HT $(30-1000 \mu \mathrm{g} / \mathrm{kg})$. For assessment of the natural absorbance of each tissue, an additional control group received an injection of saline solution without Evans Blue, followed by vehicle treatment. The vehicle treatment group did not exhibit significant basal leakiness of Evans Blue in the airways (trachea, bronchi and lung parenchyma) and upper gastrointestinal (GI) tract (esophagus and stomach) (Fig. 1). In contrast, the systemic administration of 5-HT elicited a dose-dependent increase in the amount of Evans Blue in tissues of the airways and upper GI tract, indicative of plasma extravasation (Fig. 1). A submaximal dose of 5 -HT $(100 \mu \mathrm{g} / \mathrm{kg})$ was used in all subsequent experiments.

\section{The pharmacological inhibition of $5-\mathrm{HT}_{2 \mathrm{~A}}$ attenuates plasma extravasation in the airways and esophagus}

To study the specific subtype of 5-HT receptor that is involved in 5-HT-induced plasma extravasation, mice were pre-treated with selective antagonists for 5-HT subtypes 1A (WAY-100635), 1B (GR 55562), 2A (ketanserin), 2B (RS127445), 4 (GR 113808), or 7 (SB269973). The inhibition of $5-\mathrm{HT}_{2 \mathrm{~A}}$ by ketanserin significantly attenuated plasma extravasation compared with vehicle pre-treated mice in the airways and esophagus (Fig. 2). However, ketanserin did not attenuate 5-HT-induced plasma extravasation in the stomach (Fig. 2). The inhibition of the 5-HT receptor subtypes $1 \mathrm{~A}, 1 \mathrm{~B}, 2 \mathrm{~B}, 4$, and 7 had no significant effect on 5HT-induced plasma extravasation in the airways and upper GI tract compared with vehicle pre-treated mice, indicating that only $5-\mathrm{HT}_{2 \mathrm{~A}}$ plays an important role on plasma extravasation. 
Trachea

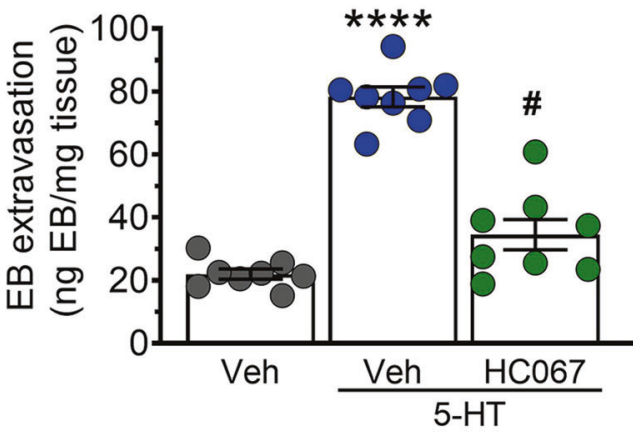

Esophagus

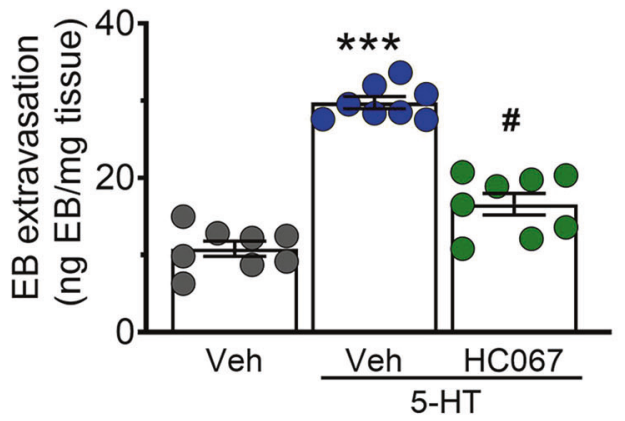

Fig. 3 Selective inhibition of TRPV4 suppresses 5-HT-induced edema. Effects of pre-treatment with the TRPV4 inhibitor HC067047 $(10 \mathrm{mg} / \mathrm{kg}, \mathrm{HC} 067)$ on 5HT-induced plasma extravasation. HC067 significantly reduced Evans Blue leakage induced by 5-HT $(100 \mu \mathrm{g} / \mathrm{kg}$, i.v. $)$. Data are expressed as mean \pm S.E.M., $n=8$ mice per

\section{TRPV4 mediates 5-HT-induced plasma extravasation in the airways and upper GI tract}

We have previously demonstrated that TRPV4 contributes to PAR1- and PAR2-dependent intracellular signaling and to PAR2-induced plasma extravasation $[20,26]$. To determine whether TRPV4 plays an equivalent role in 5-HTinduced plasma extravasation, we administered the selective TRPV4 blocker HC067047 (HC067; $10 \mathrm{mg} / \mathrm{kg}$, i.p.) prior to delivery of 5-HT. Inhibition of TRPV4 significantly decreased 5-HT-induced Evans Blue extravasation in the airways and upper GI tract, consistent with a TRPV4dependent mechanism of action (Fig. 3).

\section{5-HT-induced plasma extravasation requires TRPV4 expression}

To confirm that 5-HT-induced plasma extravasation requires TRPV4 expression, we performed equivalent studies in TRPV4 ${ }^{-/-}$mice or matched TRPV4 ${ }^{+/+}$littermates. Previously, we reported that the selective TRPV4 activator
Lung Parenchyma

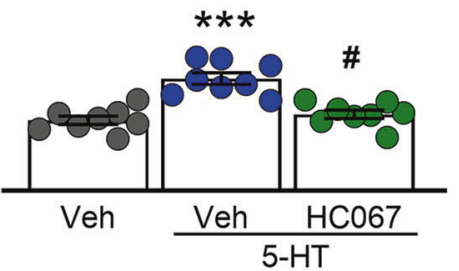
to vehicle treatment. ${ }^{\#} p<0.05$; ${ }^{\#} p<0.01$; significantly different compared to 5-HT treatment; one-way ANOVA and Dunnett's multiple comparisons test.

GSK1016790A (GSK101) induced a dose-dependent increase in plasma extravasation in wild-type mice [20]. Consistent with our prior report, the administration of GSK101 $(100 \mu \mathrm{g} / \mathrm{kg})$ to wild-type mice induced a significant increase in plasma extravasation in the airways and upper GI tract (Fig. 4). Both GSK101- and 5-HT-induced plasma extravasation were abolished in $\mathrm{TRPV}^{-1-}$ mice (Fig. 4) when compared to TRPV4 ${ }^{+/+}$mice. These data demonstrate the TRPV4-dependence of the 5-HT-evoked extravasation described.

\section{TRPV4 enhanced 5- $\mathrm{HT}_{2 \mathrm{~A}}$ calcium signaling in HEK cells}

The direct effect of 5-HT receptor signaling on TRPV4 activity was examined in an isolated cell system using HEK cells expressing the serotonin receptors $(1 \mathrm{~A}, 1 \mathrm{~B}, 2 \mathrm{~A}, 2 \mathrm{~B}$, or 4) alone or with co-expression of TRPV4. Assessment of 5HT-mediated $\mathrm{Ca}^{2+}$ signaling over time $(100 \mu \mathrm{M})$ demonstrated that HEK cells expressing $5-\mathrm{HT}_{1 \mathrm{~A}}, 1 \mathrm{~B}, 2 \mathrm{~B}$ did not exhibit increased $\left[\mathrm{Ca}^{2+}\right]_{\mathrm{i}}$ in response to 5-HT (Fig. 5A). 


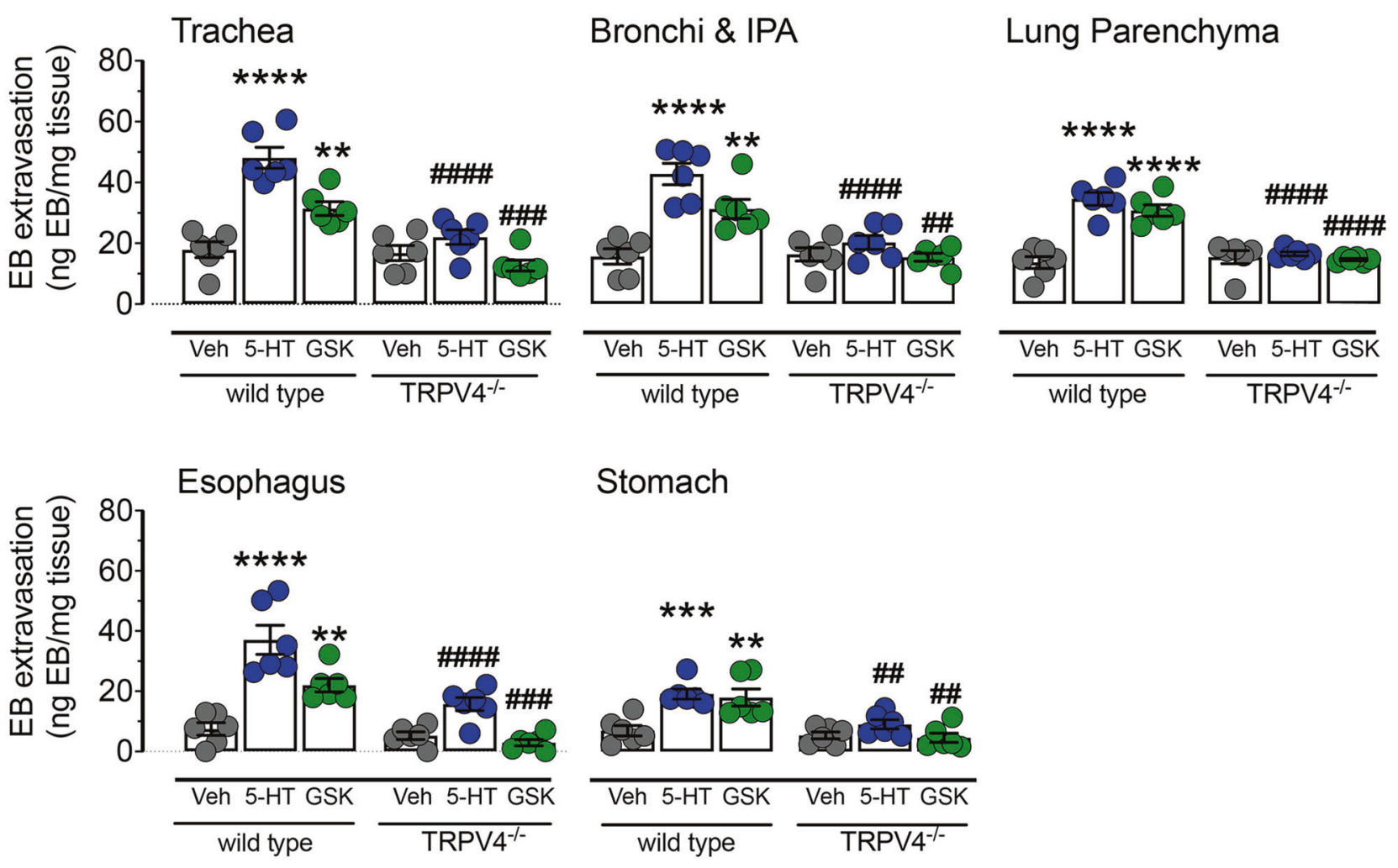

Fig. 4 5-HT and TRPV4-induced edema is absent in TRPV4 ${ }^{-1-}$ mice. The TRPV4 agonist GSK1016790A (100 $\mu \mathrm{g} / \mathrm{kg}$, i.v.; GSK) or 5HT $(100 \mu \mathrm{g} / \mathrm{kg}$, i.v.) caused significant leakage of Evans Blue in the airway and upper GI tract of wild-type mice. Both 5-HT- and TRPV4induced edema was significantly reduced in TRPV4 ${ }^{-l-}$ mice compared to wild-type littermate controls. Data are presented as mean \pm S.E.M.,

Expression of TRPV4 did not influence this response. In contrast, stimulation of HEK-5- $\mathrm{HT}_{2 \mathrm{~A}}$ cells resulted in a rapid, transient elevation in $\left[\mathrm{Ca}^{2+}\right]_{\mathrm{i}}$ that returned to baseline within $40 \mathrm{~s}$, consistent with Gq-coupled signaling. Furthermore, the duration of the $\mathrm{Ca}^{2+}$ response was markedly sustained in cells functionally expressing TRPV4 (Fig. 5B). Stimulation of HEK-5HT 4 also revealed a $\mathrm{Ca}^{2+}$ transient that was only moderately enhanced in cells co-expressing TRPV4 (Fig. 5C).

Based on the robust nature of $5 \mathrm{HT}_{2 \mathrm{~A}}-\mathrm{TRPV} 4$ coupling, we focused on 5- $\mathrm{HT}_{2 \mathrm{~A}}$ and used known mediators of GPCR-TRPV4 coupling [24] to define the signaling mechanisms involved. The 5- $\mathrm{HT}_{2 \mathrm{~A}}$ dependence of the $\mathrm{Ca}^{2+}$ response was initially confirmed using ketanserin (Fig. 5B). Changes in $\left[\mathrm{Ca}^{2+}\right]_{i}$ were then quantified over time by assessing the amplitude of the acute phase after 5-HT stimulation (0-20 s) and the magnitude of the sustained plateau phase (20-80 s post-stimulation). $5-\mathrm{HT}_{2 \mathrm{~A}}$ transactivates phospholipase A2 $\left(\mathrm{PLA}_{2}\right)$ to generate arachidonic acid (AA), an endogenous activator of TRPV4 [50-53]. $\mathrm{G}_{\mathrm{q}}$-coupled activation of Protein Kinase C (PKC) can lead to rapid phosphorylation of intracellular regulatory domains of non-selective cation channels to modulate their ionic $n=6$ mice per group. $*$ Significantly different compared to vehicle treated wild-type; $* p<0.05 ; * * p<0.01 ; * * * p<0.001 ; * * * * p<$ 0.0001. \# Significantly different compared to 5-HT- or GSK1016790A-treated wild-type; ${ }^{*} p<0.05 ;{ }^{\# \#} p<0.01 ;{ }^{\# \#} p<0.001$;

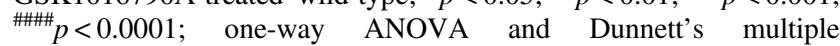
comparisons test.

permeability [24]. To determine if $\mathrm{PLA}_{2}$ and PKC serve as intermediates of 5-HT $2 \mathrm{~A}^{-}$TRPV4 coupling, cells were treated with the PLA 2 inhibitor YM $26734(30 \mu \mathrm{M})$ or the PKC inhibitor GF 109203X (GFX; $100 \mathrm{nM}$ ). Neither inhibitor affected the initial peak of the 5-HT response (Fig. 5D, E). Both inhibitors significantly suppressed the sustained phase (Fig. 5D, F). In addition, removal of extracellular $\mathrm{Ca}^{2+}$ abolished the transient and sustained phase of the 5-HTevoked $\left[\mathrm{Ca}^{2+}\right]_{i}$ response (Fig. 5D). These results suggest that coupling to TRPV4 enhances $5-\mathrm{HT}_{2 \mathrm{~A}}$ receptor signaling predominantly through influx of extracellular $\mathrm{Ca}^{2+}$.

\section{Neuropeptide receptors contribute to TRPV4- and 5- HT-induced edema}

Neuropeptides including CGRP and SP are released from sensory terminals that innervate blood vessels. These neuropeptides can influence endothelial barrier function and promote tissue edema through direct actions on microvascular endothelial cells [22, 54]. We assessed the contribution of CGRP and SP receptors to 5-HT- and TRPV4induced plasma extravasation using selective antagonists of either the CGRP receptor (Olcegepant) or $\mathrm{NK}_{1} \mathrm{R}$ 

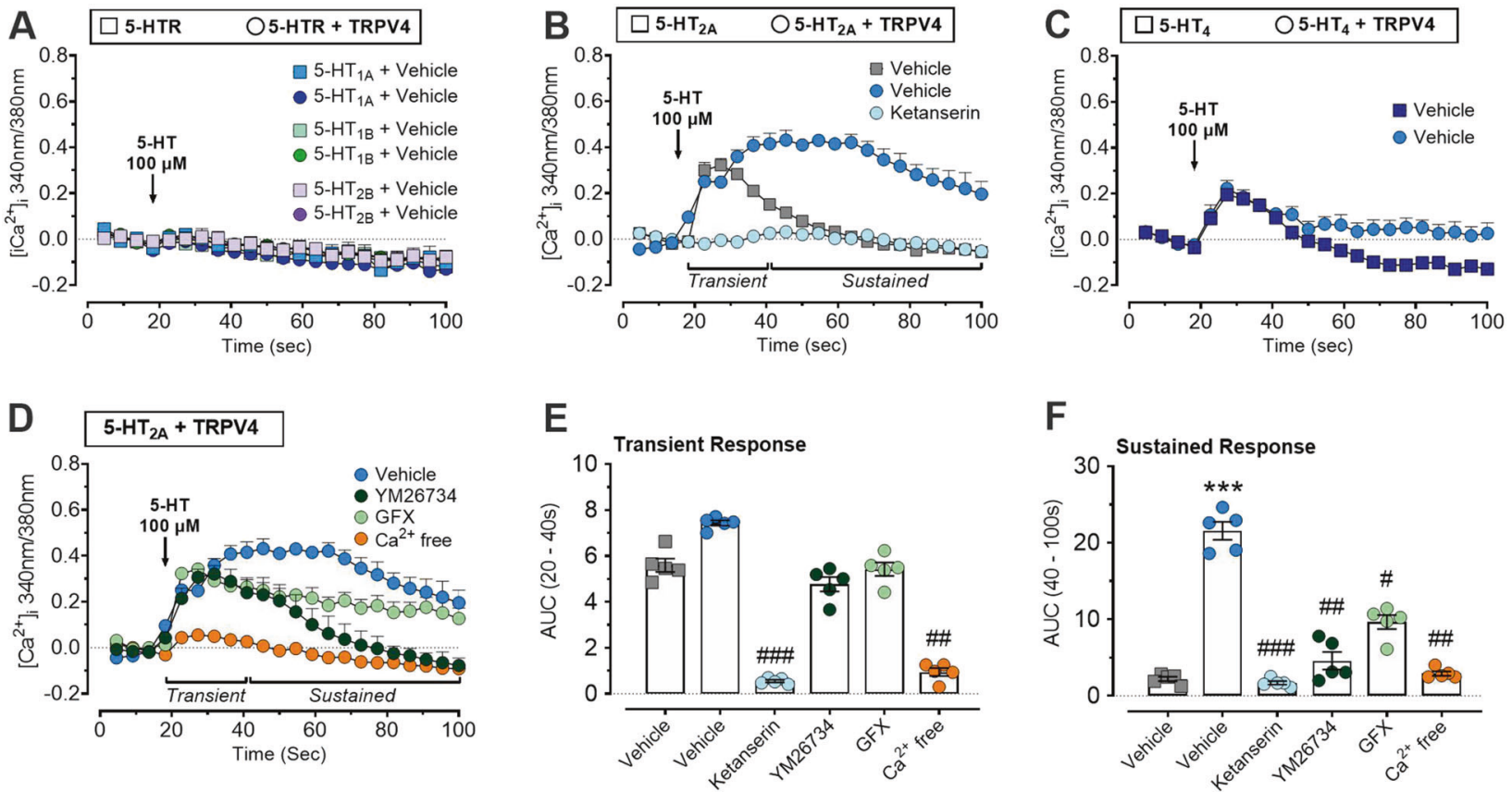

Fig. 5 5-HT induced a sustained increase in $\left[\mathrm{Ca}^{2+}\right]_{\mathrm{i}}$ in $\mathrm{HEK}$ cells co-expressing $\mathbf{5 - H T} \mathbf{H}_{2 \mathrm{~A}}$ receptor and TRPV4. A Time traces showing responses to 5 -HT $(100 \mu \mathrm{M})$ by HEK cells expressing $5-\mathrm{HT}_{1 \mathrm{~A}}, 5-\mathrm{HT}_{1 \mathrm{~B}}$ or $5-\mathrm{HT}_{2 \mathrm{~A}}$ alone (circles) or with coexpression of TRPV4 (squares). B Time traces showing responses to 5-HT $(100 \mu \mathrm{M})$ by HEK cells expressing $5-\mathrm{HT}_{2 \mathrm{~A}}$ or coexpressing $5-\mathrm{HT}_{2 \mathrm{~A}} / \mathrm{TRPV} 4$. 5-HT-induced $\left[\mathrm{Ca}^{2+}\right]_{\mathrm{i}}$ was abolished by ketanserin $(10 \mu \mathrm{M})$. C Time traces showing responses to 5-HT $(100 \mu \mathrm{M})$ by HEK cells expressing $5-\mathrm{HT}_{4}$ alone or with coexpression of TRPV4. D Effect of the depletion of extracellular

(SR140333). Both antagonists significantly decreased tissue edema in the airways, esophagus and stomach in animals treated with GSK101 (Fig. 6) and 5-HT (Fig. 7), consistent with a neurogenic mechanism of action.

\section{5-HT signaling in vascular endothelial cells is independent of TRPV4}

The direct effects of 5-HT-TRPV4 coupling on vascular endothelial cells were examined using HUVEC, which are known to functionally express both targets [20, 55]. Focusing initially on $\mathrm{Ca}^{2+}$ mobilization, exposure to 100 $\mathrm{nM}$ or $1 \mu \mathrm{M} 5$-HT did not increase in $\left[\mathrm{Ca}^{2+}\right]_{i}$. This is consistent with signaling through a $\mathrm{G}_{\mathrm{q}}$-independent mechanism (Fig. 8A). In contrast, GSK101 evoked a concentration-dependent elevation of $\left[\mathrm{Ca}^{2+}\right]_{i}$ and this was attenuated with prior treatment with $\mathrm{HC067}$ (Fig. 8A), thus confirming functional expression of TRPV4. Pretreatment with $5-\mathrm{HT} \quad(100 \mathrm{nM} ; 30 \mathrm{~min})$ enhanced GSK101-mediated $\left[\mathrm{Ca}^{2+}\right]_{\mathrm{i}}$ signaling in HUVECs (Fig. 8A, B). Specifically, 5-HT pre-treatment promoted a modest shift in $\mathrm{pEC}_{50}$ from $-8.69 \mathrm{M}$ to $-9 \mathrm{M}$ and increased $\mathrm{E}_{\max }$ from 49.52 to 64.58 (Fig. 8A). This demonstrates a significant 5-HT-evoked amplification of
$\mathrm{Ca}^{2+}, \mathrm{PLA}_{2}$ inhibitor YM $26734(30 \mu \mathrm{M})$, or PKC inhibitor GF 109203X (GFX; $100 \mathrm{nM}$ ) in HEK cells co-expressing 5-HT $2 \mathrm{~A} / \mathrm{TRPV} 4$. E, F Area under the curve analysis from 60 to $100 \mathrm{~s}$ post 5-HT $(100 \mu \mathrm{M})$ addition. Data are expressed as mean \pm SEM for $\mathrm{n}=5-6$ independent replicates. ${ }^{*} \mathrm{p}<0.05 ; * * \mathrm{p}<0.01$; One-way ANOVA and Dunnett's multiple comparisons test. * Indicates statistical significance compared to HEK cells expressing 5-HTR subtype, \# indicates statistical significance compared to HEK co-expressing 5-HTR and TRPV4.

TRPV4 signaling. Functional expression of 5-HT receptors was further confirmed by measuring levels of phosphorylated ERK (pERK), which allows for assessment of signaling through convergent pathways downstream of GPCRs. ERK activation was maximal at 2 min post-5-HT addition (100 $\mathrm{nM}$ or $1 \mu \mathrm{M})$ and decreased gradually over the $30 \mathrm{~min}$ assessment period. In contrast, GSK101 did not stimulate pERK in these cells (Fig. 8C). We confirmed that exposure to either SP $(100 \mathrm{nM}$ or $1 \mu \mathrm{M})$ or CGRP $(100 \mathrm{nM}$ or $1 \mu \mathrm{M})$ promotes a rapid and robust increase in pERK levels in HUVEC (Fig. 8D). Together, these data indicate that 5-HT receptors can sensitize and augment TRPV4 activity. These observations suggest that enhanced vascular permeability in response to 5-HT is potentially mediated through an indirect mechanism involving the TRPV4-dependent release of the neuropeptides SP and CGRP, possibly from external cellular sources such as primary afferent terminals.

\section{Discussion}

TRPV4 activation is important for the pathogenesis of pulmonary edema associated with heart failure or 


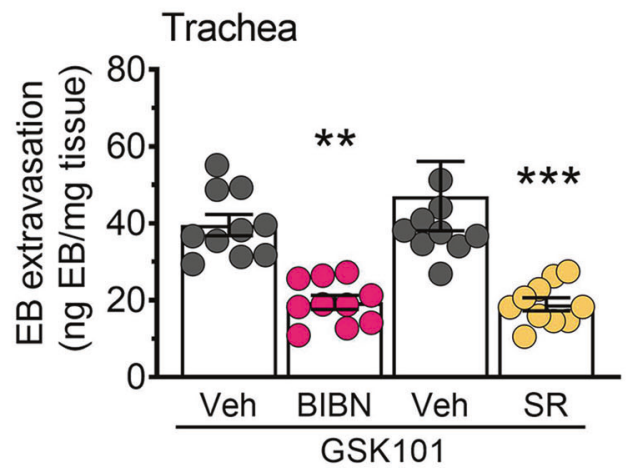

Bronchi \& IPA

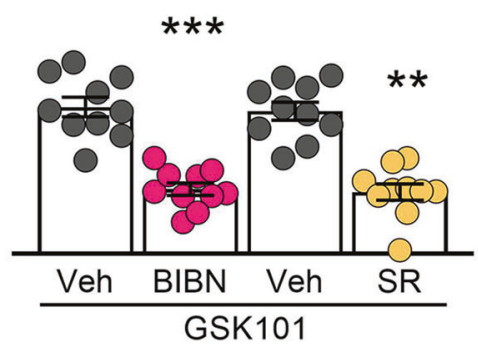

Stomach
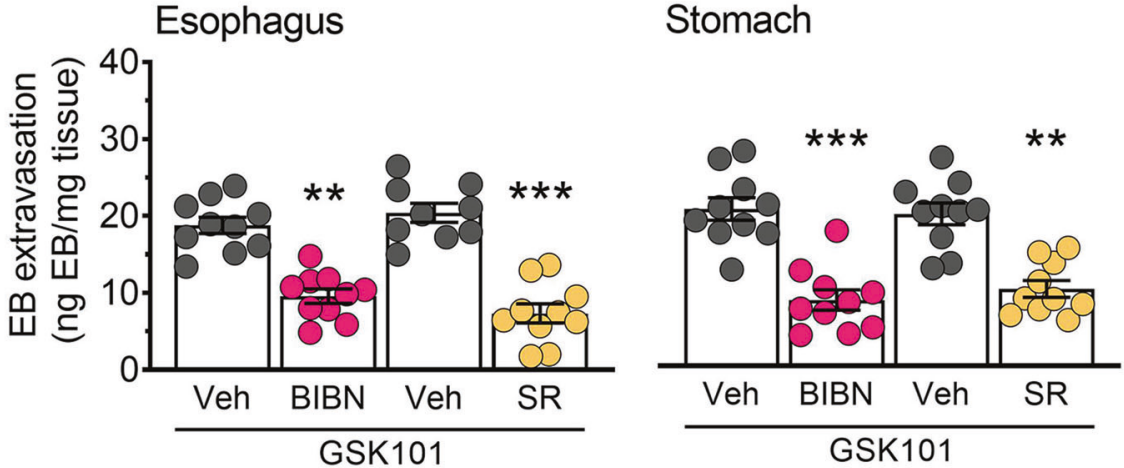

Lung Parenchyma

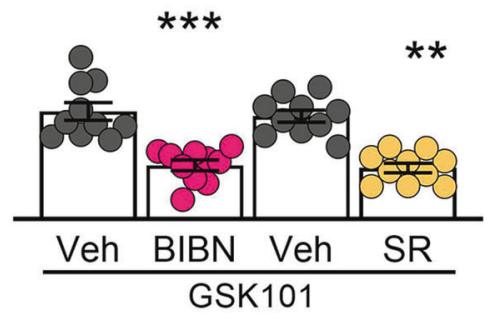

Fig. 6 TRPV4-induced edema is decreased by inhibition of CGRP or $\mathrm{NK}_{\mathbf{1}}$ receptors. Pre-treatment with the CGRP receptor antagonist BIBN4906 (BIBN; $1 \mathrm{mg} / \mathrm{kg}$ ) or $\mathrm{NK}_{1} \mathrm{R}$ antagonist SR140333 (SR; 1 $\mathrm{mg} / \mathrm{kg}$ ) significantly decreased tissue edema induced by GSK1016790A $(100 \mu \mathrm{g} / \mathrm{kg})$ compared to vehicle treatment in the

chemically-induced acute lung injury [18, 21]. TRPV4 is also a mediator of sepsis-induced endothelial dysfunction and increased vascular permeability [56]. Consistent with this, 5-HT is also a potent vasoactive and signaling mediator and can promote disruption of cell-cell junctions at concentrations not much higher than those normally present under resting conditions [56, 57]. Here, we showed that 5-HT promotes pulmonary and esophageal plasma extravasation through a TRPV4-dependent mechanism. This also involves activation of $\mathrm{NK}_{1} \mathrm{R}$ and the CGRP receptor, consistent with a putative neurogenic mechanism involving release of SP and CGRP from nerve fibers innervating the vasculature.

5-HT is mainly produced by enterochromaffin cells of the intestine, and is largely taken up and stored by platelets, or metabolized by the liver [57]. However, the lungs also play an important role in both 5-HT production and removal, and release of 5-HT by platelets may be important in the pathology of certain pulmonary diseases [57-60]. Additionally, 5-HT can be locally synthesized and released from peripheral arteries [61-63]. The 5-HTTRPV4 signaling pathway may mediate a number of pathologies, including pulmonary hypertension, arterial airways and upper GI tract. Data are presented as mean \pm S.E.M., $n=9-10$ mice per group. $* * p<0.01 ; * * * p<0.001$; One-way ANOVA and Dunnett's multiple comparisons test, significantly different compared to vehicle treated control (Veh).

smooth muscle proliferation, visceral hypersensitivity, and itch [8, 28, 30, 31]. Results of the present study suggest that the 5-HT receptor-TRPV4 axis could be an important pathway in pathologies, such as sepsis, where plasma 5-HT levels are known to be significantly elevated [64].

We have recently demonstrated that the potent and selective TRPV4 agonist, GSK101, caused dosedependent extravasation in the airways and upper GI tract of mice, which was inhibited by the selective TRPV4 antagonist HC067 [20]. In contrast, GSK101 did not cause plasma extravasation in the bladder, heart, liver or kidney, suggesting that edema is not a general systemic effect of TRPV4 activation [20]. In the present study, we report that 5-HT induces plasma extravasation in the airways, esophagus and the stomach. Plasma extravasation induced by 5-HT was decreased by HC067 or TRPV4 deletion and limited to the tissues in which the TRPV4 activation caused edema, namely the airways and upper gut. These results support a role for TRPV4 in promoting 5-HTinduced plasma extravasation in the airways, esophagus and stomach. Extravasation in response to 5-HT was almost completely blocked by the TRPV4-specific 
Trachea

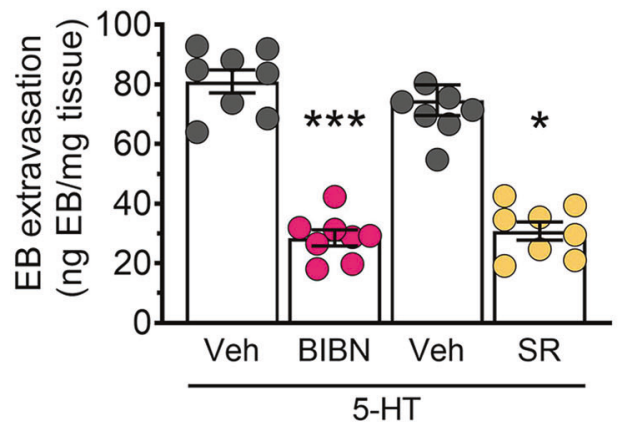

Esophagus

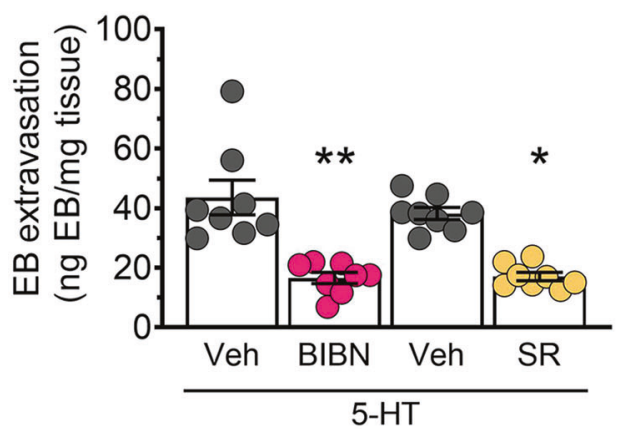

Bronchi \& IPA

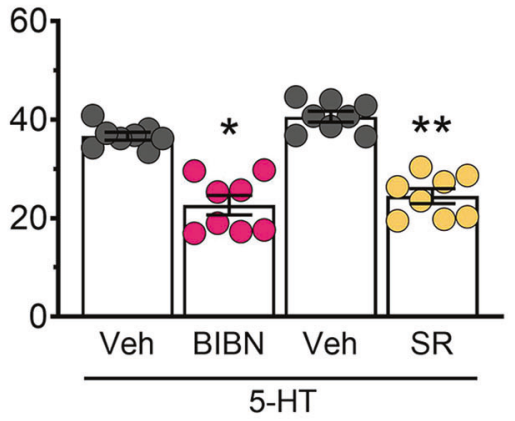

Lung Parenchyma

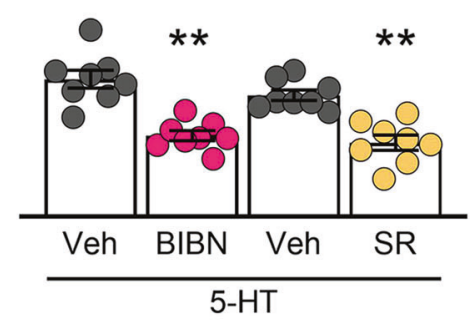

\section{Stomach}

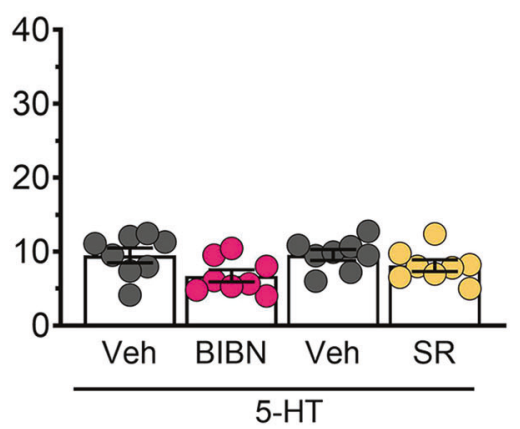

Fig. 7 Inhibition of CGRP or $\mathrm{NK}_{1}$ receptors blocks 5-HT induced edema. Pre-treatment with the CGRP receptor antagonist BIBN4906 (BIBN; $1 \mathrm{mg} / \mathrm{kg}$ ) or the $\mathrm{NK}_{1} \mathrm{R}$ antagonist SR140333 (SR; $1 \mathrm{mg} / \mathrm{kg}$ ) decreased plasma extravasation induced by $5-\mathrm{HT}(100 \mu \mathrm{g} / \mathrm{kg})$ in the airways and upper GI tract. Data are presented as mean \pm S.E.M., $n=9-10$ mice per group. $* p<0.05 ; * * p<0.01 ; * * * p<0.001$; One-way ANOVA and Dunnett's multiple comparisons test, significantly different compared to vehicle treated control (Veh).

the airways and esophagus is mediated by activation of afferent nerves, requires TRPV4, and is likely to involve release of pro-inflammatory peptides (SP and CGRP) (Fig. 9).

Pre-clinically, TRPV4 plays important roles in pathological pulmonary edema and may therefore be a therapeutically useful target. Importantly, chronic treatment with a TRPV4 inhibitor in animal models did not affect osmoregulation or interfere with the activity of diuretics, which are often used to resolve edema in the clinic [18, 7072]. Recently, a double-blind, placebo-controlled study using a selective TRPV4 antagonist reported that treatment with GSK2798745 resulted in a trend to improve pulmonary gas exchange in symptomatic patients with chronic heart failure [71, 73]. However, the use of inhibitors that directly target TRPV4 in pulmonary injury may be contraindicated by the role that TRPV4 plays in the complex signaling cascade that mediates hypoxic pulmonary vasoconstriction [74]. This mechanism helps to redistribute blood flow from poorly ventilated to more aerated lung areas, and inhibition of this response could be detrimental to patients with lung 
A

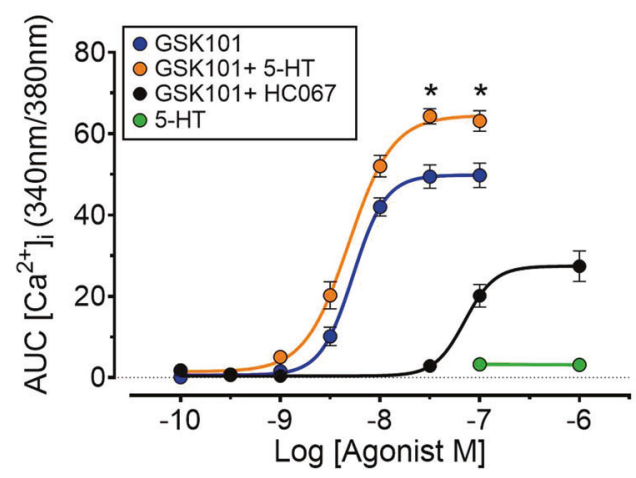

C

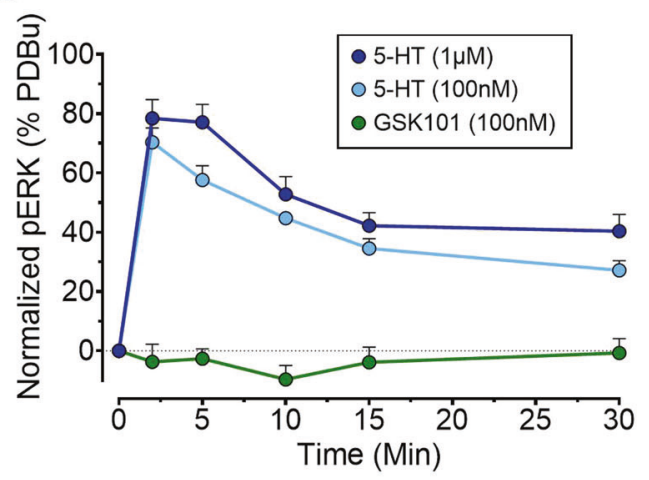

Fig. 8 Functional expression and interaction of TRPV4 and 5-HT receptors in HUVEC. A Pre-treatment with 5-HT augmented the magnitude $\left(\mathrm{E}_{\max }\right)$ of responses to GSK101. GSK101-induced $\mathrm{Ca}^{2+}$ signaling was attenuated by the TRPV4 antagonist HC067. No change in $\left[\mathrm{Ca}^{2+}\right]_{\mathrm{i}}$ was detected following treatment with 5-HT. B Time traces demonstrating the effect of pre-treatment with 5-HT (open circle, $100 \mathrm{nM}$;

disease [71, 73]. The benefits of TRPV4 antagonists for reducing pulmonary edema-associated lethality from severe acute respiratory syndrome coronavirus 2 (SARS-CoV-2) have also recently been proposed to outweigh the risks of contraindications such as these. Together, this highlights the need to further understand the relative cellular contribution of TRPV4 activity and also the upstream signaling mediators that lead to TRPV4 activation, to provide potential alternatives to these potent antagonists that directly inhibit TRPV4.

Our pharmacological data indicate that $5-\mathrm{HT}_{2 \mathrm{~A}}$ is the primary receptor subtype involved in promoting 5-HTevoked plasma extravasation. Evidence supporting the in vivo requirement for TRPV4 activity is provided by the demonstration that $5-\mathrm{HT}_{2 \mathrm{~A}}$ mediated $\mathrm{Ca}^{2+}$ signaling is augmented by TRPV4 through a $\mathrm{PLA}_{2^{-}}$and PKCdependent mechanism. Although our data support an indirect neurogenic mechanism of action involving enhanced neuropeptide release [23], the specific locations where $5-\mathrm{HT}_{2 \mathrm{~A}}$-TRPV4 interactions occur (pre- or postsynaptic [75]) could not be definitively determined using available methodology. We cannot exclude a direct effect
B
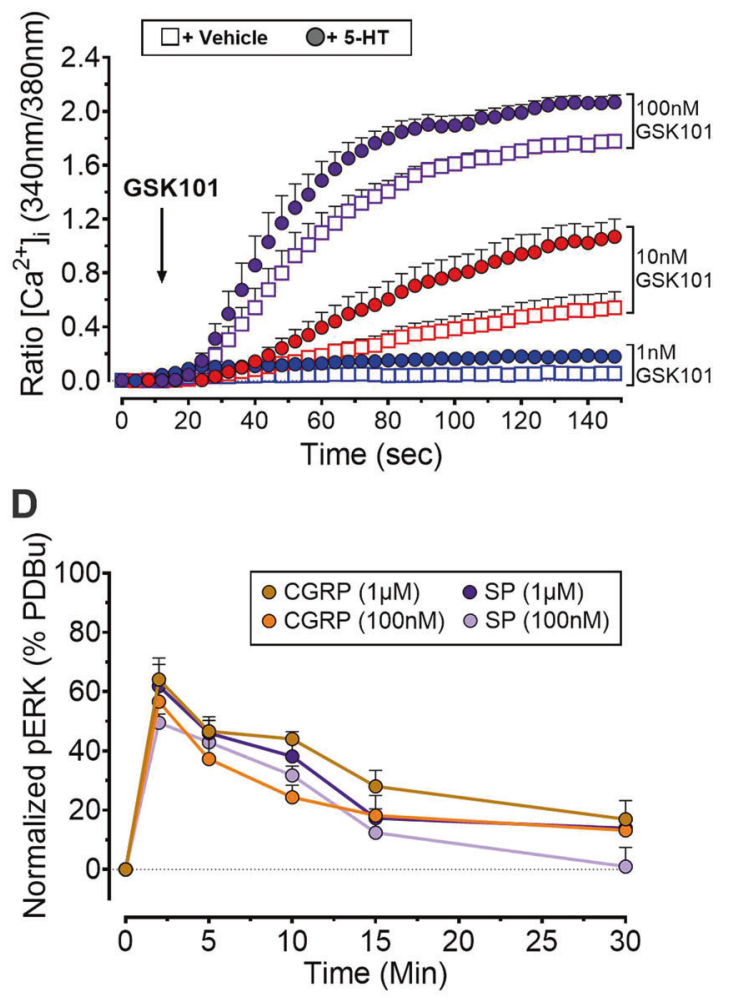

$30 \mathrm{~min}$ ) on GSK101-induced elevations in $\left[\mathrm{Ca}^{2+}\right]_{\mathrm{i}}$ (closed circles). C, D Elevated ERK phosphorylation (pERK) in response to treatment of HUVEC with 5-HT, GSK101, CGRP or SP. Data are presented as mean \pm S.E.M., $n=6$ technical replicates, pERK data are normalized to the positive control (PDBu, $1 \mu \mathrm{M})$.

on endothelial cells as the HUVEC that we examined may not be the most suitable model for the microvasculature involved in 5-HT-dependent vascular leak as they are of a different origin and may not express the precise machinery required. Our results suggest that 5-HT and TRPV4 receptors are also expressed by endothelial cells and may cause protein leak via disruption of the vascular junctions in mice. In addition to expression by peptidergic afferent nerves [76] and vascular endothelial cells [77, 78], 5-HT receptors and TRPV4 are also expressed by immune cells, including macrophages [79-81]. Given the important immunomodulatory role of 5-HT, it is possible that the TRPV4-dependent effects of 5-HT on vascular permeability that we describe are mediated in part through immune cell activation. Future analysis to better define the relative contributions of 5-HT receptors and TRPV4 in endothelial and immune cells and on nerve endings of the different vascular beds would help to clarify the primary location of TRPV4-driven edema and the precise mechanisms involved.

In summary, we have established that TRPV4 mediates 5-HT-induced plasma extravasation in the airways and 


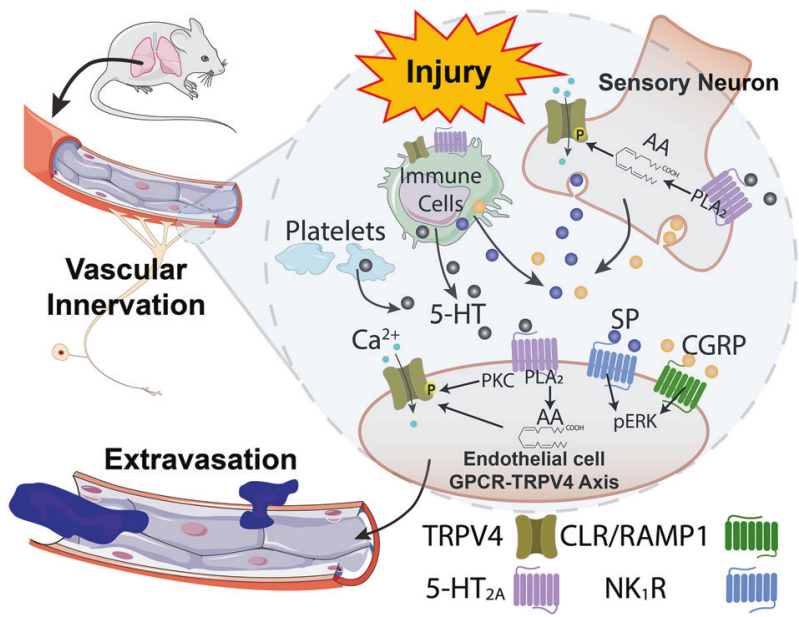

Fig. 9 Postulated neurogenic and direct mechanisms through which 5-HT receptors and TRPV4 may induce tissue edema. 5-HT activates $5-\mathrm{HT}_{2 \mathrm{~A}}$ receptor subtypes on afferent nerve terminals, immune cells, and vascular endothelial cells. Activation of peripheral sensory neurons or local immune cells promotes release of neuropeptides including SP and CGRP, activating $\mathrm{NK}_{1} \mathrm{R}$ and CGRP receptors expressed by endothelial cells. Signaling downstream of these receptors leads to retraction of cell-cell junction proteins, leading to increased vascular leak and to tissue edema. Activation of 5-HT $2 \mathrm{~A}$ sensitizes or activates TRPV4 through a $\mathrm{PLA}_{2-}$ and PKC-dependent mechanism, leading to enhanced neuropeptide release.

upper GI tract of mice through interaction with the $5-\mathrm{HT}_{2 \mathrm{~A}}$ receptor subtype. We have provided evidence to support an indirect, potentially neurogenic mechanism of action involving the neuropeptides SP and CGRP.

\section{Data availability}

Data presented in this study are available upon request from the corresponding authors.

Acknowledgements The authors thank Dr Wolfgang Liedtke (Duke University) for providing TRPV4 ${ }^{-1-}$ mice.

Author contributions Participated in research design: JSR, MSG, NWB, NAV, DPP, and PM. Conducted experiments: MSG, LKD, SP, FB, JSR, JGA, and SA. Performed data analysis: JSR, NAV, DPP, MSG, and PM. Contributed to writing or critical assessment of the paper: JSR, MSG, ABG, PR, PRG, SEC, NAV, DPP, and PM.

Funding Australian Research Council Center of Excellence in Convergent Bio-Nano Science and Technology (TPD, NWB, and NAV), NHMRC Australia 1046860 (PM, NWB), 1083480 (DPP).

\section{Compliance with ethical standards}

Conflict of interest The authors declare no competing interests.

Ethical approval Studies using mice were approved by the Animal Ethics Committees of RMIT and Monash Institute of Pharmaceutical Sciences.
Publisher's note Springer Nature remains neutral with regard to jurisdictional claims in published maps and institutional affiliations.

\section{References}

1. Tiruppathi C, Ahmmed GU, Vogel SM, Malik AB. $\mathrm{Ca}^{2+}$ signaling, TRP channels, and endothelial permeability. Microcirculation. 2006;13:693-708.

2. Tiruppathi C, Minshall RD, Paria BC, Vogel SM, Malik AB. Role of $\mathrm{Ca}^{2+}$ signaling in the regulation of endothelial permeability. Vascul Pharmacol. 2002;39:173-85.

3. Bhattacharya J, Nanjo S, Staub NC. Micropuncture measurement of lung microvascular pressure during 5-HT infusion. J Appl Physiol Respir Environ Exerc Physiol. 1982;52:634-7.

4. Friedrich EE, Hong Z, Xiong S, Zhong M, Di A, Rehman J, et al. Endothelial cell Piezo1 mediates pressure-induced lung vascular hyperpermeability via disruption of adherens junctions. Proc Natl Acad Sci USA. 2019;116:12980-5.

5. Lee $\mathrm{HZ}, \mathrm{Wu} \mathrm{CH}$. Serotonin-stimulated increase in cytosolic $\mathrm{Ca}{ }^{2}$ ${ }^{+}$) in cultured rat heart endothelial cells. Eur J Pharmacol. 1999;384:53-60.

6. Stolwijk JA, Zhang X, Gueguinou M, Zhang W, Matrougui K, Renken C, et al. Calcium signaling is dispensable for receptor regulation of endothelial barrier function. $\mathrm{J}$ Biol Chem. 2016;291:22894-912.

7. Kamiya I, Sumita T, Ishikawa N. S1-receptor participation in serotonin-induced pulmonary edema in the dog. Jpn J Pharmacol. 1987;45:121-4.

8. Xia Y, Fu Z, Hu J, Huang C, Paudel O, Cai S, et al. TRPV4 channel contributes to serotonin-induced pulmonary vasoconstriction and the enhanced vascular reactivity in chronic hypoxic pulmonary hypertension. Am J Physiol Cell Physiol. 2013;305: C704-15.

9. Majno G, Palade GE. Studies on inflammation. 1. The effect of histamine and serotonin on vascular permeability: an electron microscopic study. J Biophys Biochem Cytol. 1961;11:571-605.

10. Andrade R, Barnes NM, Baxter G, Bockaert J, Branchek T, Butler A, et al. 5-Hydroxytryptamine receptors (version 2019.4) in the IUPHAR/BPS Guide to Pharmacology Database. IUPHAR/BPS Guide to Pharmacology CITE Volume 2019, No. 4. 2019.

11. Barnes NM, Sharp T. A review of central 5-HT receptors and their function. Neuropharmacology. 1999;38:1083-152.

12. Koo JW, Balaban CD. Serotonin-induced plasma extravasation in the murine inner ear: possible mechanism of migraine-associated inner ear dysfunction. Cephalalgia. 2006;26:1310-9.

13. Ayme-Dietrich E, Aubertin-Kirch G, Maroteaux L, Monassier L. Cardiovascular remodeling and the peripheral serotonergic system. Arch Cardiovasc Dis. 2017;110:51-9.

14. Yildiz O, Smith JR, Purdy RE. Serotonin and vasoconstrictor synergism. Life Sci. 1998;62:1723-32.

15. Tran QK, Ohashi K, Watanabe H. Calcium signalling in endothelial cells. Cardiovasc Res. 2000;48:13-22.

16. Dalal PJ, Muller WA, Sullivan DP. Endothelial cell calcium signaling during barrier function and inflammation. Am J Pathol. 2020;190:535-42.

17. Thakore P, Earley S. Transient receptor potential channels and endothelial cell calcium signaling. Compr Physiol. 2019;9:1249-77.

18. Huh D, Leslie DC, Matthews BD, Fraser JP, Jurek S, Hamilton $\mathrm{GA}$, et al. A human disease model of drug toxicity-induced pulmonary edema in a lung-on-a-chip microdevice. Sci Transl Med. 2012;4:159ra147.

19. Morgan JT, Stewart WG, McKee RA, Gleghorn JP. The mechanosensitive ion channel TRPV4 is a regulator of lung 
development and pulmonary vasculature stabilization. Cell Mol Bioeng. 2018;11:309-20.

20. Peng S, Grace MS, Gondin AB, Retamal JS, Dill L, Darby W, et al. The transient receptor potential vanilloid 4 (TRPV4) ion channel mediates protease activated receptor 1 (PAR1)-induced vascular hyperpermeability. Lab Investig. 2020;100:1057-67.

21. Balakrishna S, Song W, Achanta S, Doran SF, Liu B, Kaelberer MM, et al. TRPV4 inhibition counteracts edema and inflammation and improves pulmonary function and oxygen saturation in chemically induced acute lung injury. Am J Physiol Lung Cell Mol Physiol. 2014;307:L158-72.

22. Queiroz BFG, Almeida MPA, Bakhle YS, Francischi JN. Calcitonin-gene related peptide is a potent inducer of oedema in rat orofacial tissue. Neuropeptides. 2018;68:43-8.

23. Vergnolle N, Cenac N, Altier C, Cellars L, Chapman K, Zamponi $\mathrm{GW}$, et al. A role for transient receptor potential vanilloid 4 in tonicity-induced neurogenic inflammation. $\mathrm{Br} \mathrm{J}$ Pharmacol. 2010;159:1161-73.

24. Veldhuis NA, Poole DP, Grace M, McIntyre P, Bunnett NW. The $G$ protein-coupled receptor-transient receptor potential channel axis: molecular insights for targeting disorders of sensation and inflammation. Pharmacol Rev. 2015;67:36-73.

25. Grant AD, Cottrell GS, Amadesi S, Trevisani M, Nicoletti P, Materazzi S, et al. Protease-activated receptor 2 sensitizes the transient receptor potential vanilloid 4 ion channel to cause mechanical hyperalgesia in mice. J Physiol. 2007;578:715-33.

26. Poole DP, Amadesi S, Veldhuis NA, Abogadie FC, Lieu T, Darby $\mathrm{W}$, et al. Protease-activated receptor 2 (PAR2) protein and transient receptor potential vanilloid 4 (TRPV4) protein coupling is required for sustained inflammatory signaling. J Biol Chem. 2013;288:5790-802.

27. Grace MS, Lieu T, Darby B, Abogadie FC, Veldhuis N, Bunnett NW, et al. The tyrosine kinase inhibitor bafetinib inhibits PAR2induced activation of TRPV4 channels in vitro and pain in vivo. Br J Pharmacol. 2014;171:3881-94.

28. Ducret T, Guibert C, Marthan R, Savineau JP. Serotonin-induced activation of TRPV4-like current in rat intrapulmonary arterial smooth muscle cells. Cell Calcium. 2008;43:315-23.

29. Ahn MS, Eom YW, Oh JE, Cha SK, Park KS, Son JW, et al. Transient receptor potential channel TRPV4 mediates TGF-beta1induced differentiation of human ventricular fibroblasts. Cardiol J. 2020;27:162-70.

30. Akiyama T, Ivanov M, Nagamine M, Davoodi A, Carstens MI, Ikoma A, et al. Involvement of TRPV4 in serotonin-evoked scratching. J Investig Dermatol. 2016;136:154-60.

31. Cenac N, Altier C, Motta JP, d'Aldebert E, Galeano S, Zamponi GW, et al. Potentiation of TRPV4 signalling by histamine and serotonin: an important mechanism for visceral hypersensitivity. Gut. 2010;59:481-8.

32. Maeshima T, Ito R, Hamada S, Senzaki K, Hamaguchi-Hamada $\mathrm{K}$, Shutoh F, et al. The cellular localization of 5-HT2A receptors in the spinal cord and spinal ganglia of the adult rat. Brain Res. 1998;797:118-24.

33. Okamoto K, Imbe H, Morikawa Y, Itoh M, Sekimoto M, Nemoto $\mathrm{K}$, et al. 5-HT2A receptor subtype in the peripheral branch of sensory fibers is involved in the potentiation of inflammatory pain in rats. Pain. 2002;99:133-43.

34. Chiu IM, von Hehn CA, Woolf CJ. Neurogenic inflammation and the peripheral nervous system in host defense and immunopathology. Nat Neurosci. 2012;15:1063-7.

35. Nascimento EB Jr., Seniuk JG, Godin AM, Ferreira WC, Dutra $\mathrm{MB}$, Oliveira AC, et al. Peripheral 5-HT1B and 5-HT2A receptors mediate the nociceptive response induced by 5 -hydroxytryptamine in mice. Pharmacol Biochem Behav. 2011;99:598-603.

36. Saria A, Lundberg JM, Skofitsch G, Lembeck F. Vascular protein linkage in various tissue induced by substance $\mathrm{P}$, capsaicin, bradykinin, serotonin, histamine and by antigen challenge. Naunyn Schmiedebergs Arch Pharmacol. 1983;324:212-8.

37. Sasaki M, Obata H, Kawahara K, Saito S, Goto F. Peripheral 5HT2A receptor antagonism attenuates primary thermal hyperalgesia and secondary mechanical allodynia after thermal injury in rats. Pain. 2006;122:130-6.

38. Sukriti S, Tauseef M, Yazbeck P, Mehta D. Mechanisms regulating endothelial permeability. Pulm Circ. 2014;4:535-51.

39. Markowitz S, Saito K, Moskowitz MA. Neurogenically mediated leakage of plasma protein occurs from blood vessels in dura mater but not brain. J Neurosci. 1987;7:4129-36.

40. Ramachandran R. Neurogenic inflammation and its role in migraine. Semin Immunopathol. 2018;40:301-14.

41. Tajti J, Szok D, Majlath Z, Tuka B, Csati A, Vecsei L. Migraine and neuropeptides. Neuropeptides. 2015;52:19-30.

42. Kilkenny C, Browne WJ, Cuthill IC, Emerson M, Altman DG. Improving bioscience research reporting: the ARRIVE guidelines for reporting animal research. PLoS Biol. 2010;8:e1000412.

43. Misane I, Ogren SO. Selective 5-HT1A antagonists WAY 100635 and NAD-299 attenuate the impairment of passive avoidance caused by scopolamine in the rat. Neuropsychopharmacology. 2003;28:253-64.

44. Hansen-Schwartz J, Lovland Hoel N, Nilsson E, Tfelt-Hansen P, Edvinsson L. Endothelium-dependent relaxant responses to selective 5-HT(1B/1D) receptor agonists in the isolated middle cerebral artery of the rat. J Vasc Res. 2003;40:561-6.

45. Ninan I, Kulkarni SK. Ketanserin reverses dizocilpine-suppression of morphine dependence but not tolerance in mice. Brain Res. 2000;876:215-9.

46. Mbaki Y, Ramage AG. Investigation of the role of 5-HT2 receptor subtypes in the control of the bladder and the urethra in the anaesthetized female rat. Br J Pharmacol. 2008;155:343-56.

47. Spohn SN, Bianco F, Scott RB, Keenan CM, Linton AA, O'Neill $\mathrm{CH}$, et al. Protective actions of epithelial 5-hydroxytryptamine 4 receptors in normal and inflamed colon. Gastroenterology. 2016;151:933-44.e3.

48. Swain SM, Romac JM, Shahid RA, Pandol SJ, Liedtke W, Vigna $\mathrm{SR}$, et al. TRPV4 channel opening mediates pressure-induced pancreatitis initiated by Piezo1 activation. J Clin Investig. 2020;130:2527-41.

49. Wick MJ, Harral JW, Loomis ZL, Dempsey EC. An optimized evans blue protocol to assess vascular leak in the mouse. J Vis Exp. 2018;57037.

50. Kurrasch-Orbaugh DM, Parrish JC, Watts VJ, Nichols DE. A complex signaling cascade links the serotonin2A receptor to phospholipase A2 activation: the involvement of MAP kinases. J Neurochem. 2003a;86:980-91.

51. Kurrasch-Orbaugh DM, Watts VJ, Barker EL, Nichols DE. Serotonin 5-hydroxytryptamine $2 \mathrm{~A}$ receptor-coupled phospholipase $\mathrm{C}$ and phospholipase A2 signaling pathways have different receptor reserves. J Pharmacol Exp Ther. 2003b;304:229-37.

52. Qu Y, Villacreses N, Murphy DL, Rapoport SI. 5-HT2A/2C receptor signaling via phospholipase A2 and arachidonic acid is attenuated in mice lacking the serotonin reuptake transporter. Psychopharmacology. 2005;180:12-20.

53. Watanabe H, Vriens J, Prenen J, Droogmans G, Voets T, Nilius B. Anandamide and arachidonic acid use epoxyeicosatrienoic acids to activate TRPV4 channels. Nature. 2003;424:434-8.

54. Baluk P, Thurston G, Murphy TJ, Bunnett NW, McDonald DM. Neurogenic plasma leakage in mouse airways. Br J Pharmacol. 1999;126:522-8.

55. Machida T, Iizuka K, Hirafuji M. 5-hydroxytryptamine and its receptors in systemic vascular walls. Biol Pharm Bull. 2013;36:1416-9.

56. Dalsgaard T, Sonkusare SK, Teuscher C, Poynter ME, Nelson MT. Pharmacological inhibitors of TRPV4 channels reduce 
cytokine production, restore endothelial function and increase survival in septic mice. Sci Rep. 2016;6:33841.

57. Egermayer P, Town GI, Peacock AJ. Role of serotonin in the pathogenesis of acute and chronic pulmonary hypertension. Thorax. 1999;54:161-8.

58. Cloutier N, Allaeys I, Marcoux G, Machlus KR, Mailhot B, Zufferey A, et al. Platelets release pathogenic serotonin and return to circulation after immune complex-mediated sequestration. Proc Natl Acad Sci USA. 2018;115:E1550-9.

59. Duerschmied D, Suidan GL, Demers M, Herr N, Carbo C, Brill A, et al. Platelet serotonin promotes the recruitment of neutrophils to sites of acute inflammation in mice. Blood. 2013;121:1008-15.

60. Ulrich S, Huber LC, Fischler M, Treder U, Maggiorini M, Eberli FR, et al. Platelet serotonin content and transpulmonary platelet serotonin gradient in patients with pulmonary hypertension. Respiration. 2011;81:211-6.

61. Neumann J, Hofmann B, Gergs U. Production and function of serotonin in cardiac cells. In Shad KF, editor. Serotonin-a chemical messenger between all types of living cells. London: IntechOpen; 2017.

62. Ni W, Geddes TJ, Priestley JR, Szasz T, Kuhn DM, Watts SW. The existence of a local 5-hydroxytryptaminergic system in peripheral arteries. Br J Pharmacol. 2008;154:663-74.

63. Rouzaud-Laborde C, Hanoun N, Baysal I, Rech JS, Mias C, Calise D, et al. Role of endothelial AADC in cardiac synthesis of serotonin and nitrates accumulation. PLoS ONE. 2012;7:e34893.

64. Li Y, Hadden C, Cooper A, Ahmed A, Wu H, Lupashin VV, et al. Sepsis-induced elevation in plasma serotonin facilitates endothelial hyperpermeability. Sci Rep. 2016;6:22747.

65. Groneberg DA, Quarcoo D, Frossard N, Fischer A. Neurogenic mechanisms in bronchial inflammatory diseases. Allergy. 2004;59:1139-52.

66. Aoki-Nagase T, Nagase T, Oh-Hashi Y, Kurihara Y, Yamaguchi $\mathrm{Y}$, Yamamoto $\mathrm{H}$, et al. Calcitonin gene-related peptide mediates acid-induced lung injury in mice. Respirology. 2007;12:807-13.

67. Sio SW, Puthia MK, Lu J, Moochhala S, Bhatia M. The neuropeptide substance $\mathrm{P}$ is a critical mediator of burn-induced acute lung injury. J Immunol. 2008;180:8333-41.

68. Rogers DF, Belvisi MG, Aursudkij B, Evans TW, Barnes PJ. Effects and interactions of sensory neuropeptides on airway microvascular leakage in guinea-pigs. $\mathrm{Br} \mathrm{J}$ Pharmacol. 1988;95:1109-16.

69. Bileviciute I, Stenfors C, Theodorsson E, Lundeberg T. Unilateral injection of calcitonin gene-related peptide (CGRP) induces bilateral oedema formation and release of CGRP-like immunoreactivity in the rat hindpaw. Br J Pharmacol. 1998;125:1304-12.
70. Dietrich A. Modulators of transient receptor potential (TRP) channels as therapeutic options in lung disease. Pharmaceuticals (Basel). 2019;12:23.

71. Goyal N, Skrdla P, Schroyer R, Kumar S, Fernando D, Oughton A, et al. Clinical pharmacokinetics, safety, and tolerability of a novel, first-in-class TRPV4 ion channel inhibitor, GSK2798745, in healthy and heart failure subjects. Am J Cardiovasc Drugs. 2019;19:335-42.

72. Kuebler WM, Jordt SE, Liedtke WB. Urgent reconsideration of lung edema as a preventable outcome in COVID-19: inhibition of TRPV4 represents a promising and feasible approach. Am J Physiol Lung Cell Mol Physiol. 2020;318:L1239-43.

73. Stewart GM, Johnson BD, Sprecher DL, Reddy YNV, Obokata M, Goldsmith S, et al. Targeting pulmonary capillary permeability to reduce lung congestion in heart failure: a randomized, controlled pilot trial. Eur J Heart Fail. 2020;22:1641-5.

74. Yang XR, Lin AH, Hughes JM, Flavahan NA, Cao YN, Liedtke $\mathrm{W}$, et al. Upregulation of osmo-mechanosensitive TRPV4 channel facilitates chronic hypoxia-induced myogenic tone and pulmonary hypertension. Am J Physiol Lung Cell Mol Physiol. 2012;302: L555-68.

75. Zhao H, Sprunger LK, Simasko SM. Expression of transient receptor potential channels and two-pore potassium channels in subtypes of vagal afferent neurons in rat. Am J Physiol Gastrointest Liver Physiol. 2010;298:G212-21.

76. Brierley SM, Page AJ, Hughes PA, Adam B, Liebregts T, Cooper $\mathrm{NJ}$, et al. Selective role for TRPV4 ion channels in visceral sensory pathways. Gastroenterology. 2008;134:2059-69.

77. Kohler R, Heyken WT, Heinau P, Schubert R, Si H, Kacik M, et al. Evidence for a functional role of endothelial transient receptor potential V4 in shear stress-induced vasodilatation. Arterioscler Thromb Vasc Biol. 2006;26:1495-502.

78. Sonkusare SK, Bonev AD, Ledoux J, Liedtke W, Kotlikoff MI, Heppner TJ, et al. Elementary $\mathrm{Ca}^{2+}$ signals through endothelial TRPV4 channels regulate vascular function. Science. 2012;336:597-601.

79. Ahern GP. 5-HT and the immune system. Curr Opin Pharmacol. 2011;11:29-33.

80. Hamanaka K, Jian MY, Townsley MI, King JA, Liedtke W, Weber DS, et al. TRPV4 channels augment macrophage activation and ventilator-induced lung injury. Am J Physiol Lung Cell Mol Physiol. 2010;299:L353-62.

81. Scheraga RG, Abraham S, Niese KA, Southern BD, Grove LM, Hite RD, et al. TRPV4 mechanosensitive ion channel regulates lipopolysaccharide-stimulated macrophage phagocytosis. J Immunol. 2016;196:428-36. 